\title{
Feeding manipulation elicits different proliferative responses in the gastrointestinal tract of suckling and weanling rats
}

\section{A.C. Palanch and E.P. Alvares}

\author{
Departamento de Histologia e Embriologia, Instituto de Ciências Biomédicas, \\ Universidade de São Paulo, São Paulo, SP, Brasil
}

\section{Correspondence \\ E.P. Alvares \\ Departamento de Histologia e \\ Embriologia, ICB, USP \\ Av. Professor Lineu Prestes, 1524 \\ 05508-900 São Paulo, SP \\ Brasil \\ Fax: 55 (011) 818-7402}

Research supported in part by FAPESP. A.C. Palanch was the recipient of a CAPES fellowship.

Received July 18, 1997 Accepted January 12, 1998

\section{Abstract}

Food deprivation has been found to stimulate cell proliferation in the gastric mucosa of suckling rats, whereas the weanling period has been reported to be unresponsive in terms of proliferative activity. In the present study we analyze regional differences in the effect of milk or food deprivation on cell proliferation of the epithelia of the esophagus and of five segments of small intestine in suckling, weanling and newly weaned Wistar rats of both sexes. DNA synthesis was determined using tritiated thymidine to obtain labeling indices (LI); crypt depth and villus height were also determined. Milk deprivation decreased LI by $50 \%$ in the esophagus (from 15 to $8.35 \%$ ) and small intestine (from 40 to $20 \%$ ) of 14-day-old rats. In 18-day-old rats, milk and food deprivation decreased LI in the esophagus (from 13 to 5\%) and in the distal segments of the small intestine (from 36-40 to 24$32 \%$ ). In contrast, the LI of the epithelia of the esophagus (5\%) and of all small intestine segments (around 30\%) of 22-day-old rats were not modified by food deprivation. Crypt depth did not change after treatment (80 to $120 \mu \mathrm{m}$ in 14- and 22-day-old rats, respectively). Villus height decreased in some small intestine segments of unfed 14(from 400 to $300 \mu \mathrm{m}$ ) and 18-day-old rats (from 480 to $360 \mu \mathrm{m}$ ). The results show that, contrary to the stomach response, milk deprivation inhibited cell proliferation in the esophagus and small intestine of suckling rats, demonstrating the regional variability of each segment of the gastrointestinal tract in suckling rats. In newly weaned rats, food deprivation did not alter the proliferation of these epithelia, similarly to the stomach, indicating that weanling is a period marked by the insensitivity of gastrointestinal epithelia to dietary alterations.

\section{Introduction}

Milk contains relatively large amounts of hormones and growth factors (1). Many of these peptides have been suggested to stimulate the development of the gastrointestinal tract in newborn and weanling rats (2). At
Key words

- Developing rats

- Milk deprivation

- Cell proliferation

- Crypt and villus size

- Esophagus

- Small intestine the same time, we have demonstrated the action of inhibitory hormones, present in milk, on cell proliferation of the gastric epithelium (3). Furthermore, milk restriction during suckling increased proliferative indices in the stomach (4). During weanling, however, food restriction had no effect on 
the proliferative activity of gastric epithelium (5).

It is well known that food deprivation inhibits gastric $(6,7)$ and intestinal epithelial cell proliferation in adult rats $(8,9)$. The size of the crypts and villi (9), the migration rate (10), and the crypt cell production rate (11) are also decreased in food-deprived adult rats. These starvation-induced hypoproliferative responses have been attributed to the increase in cell cycle time (11).

Few studies have examined the effect of food (or milk) deprivation on cell proliferation of suckling rats. A recent study on the intestinal mucosa demonstrated that starvation of 12- and 13-day-old rats decreased the migration rate; however, DNA incorporation of $\left[{ }^{3} \mathrm{H}\right]$-thymidine after $16 \mathrm{~h}$ of milk deprivation was similar to control values for the intestine of 12-day-old suckling rats (12).

The esophagus of the rat has received much less attention. Recently, the ultrastructure of the fetal and neonatal esophageal epithelium of the mouse was described in detail but only the proliferative indices of the fetal epithelium were measured (13).

In an attempt to understand the unexpected stimulation of proliferation of the gastric mucosa, in the present study we compared the effects of milk or food restriction on the esophagus and five segments of small intestine epithelia at different times in suckling, weanling and newly weaned rats. Cell proliferation was assessed by the DNA synthesis index and by estimation of the size of proliferative compartments.

\section{Material and Methods}

\section{Animals}

Pregnant Wistar rats were obtained from our animal colony (Institute of Biomedical Sciences). The birth date was taken as day 0 and litters were culled to eight animals on the second day. The animals were kept at room temperature on a natural light period from about 5:30 to 18:30 h. All suckling and weanling pups were allowed to stay with the dam until the time of milk or food deprivation treatment. Two groups of two or three animals were obtained from each litter; one remained with the mother and the other was housed in paper boxes (14 days) or wire cages (18 and 21 days). Sometimes, only two or four animals of one litter were utilized in fed and unfed pairs to avoid overfeeding. The animals were kept warm (temperature $20-25^{\circ} \mathrm{C}$ ), had their bellies manipulated to aid urine expulsion and were given water manually. Suckling (14-day-old) and weanling (18-day-old) rats were starved for 18 and $20 \mathrm{~h}$, respectively, before the experiment. The 22-day-old rats were weaned on the 20th day and food deprived for $24 \mathrm{~h}$.

\section{Organ preparation}

Rats were injected ip with $\left[{ }^{3} \mathrm{H}\right]$-thymidine at $37 \mathrm{kBq} / \mathrm{g}$ body weight, specific activity $0.74 \mathrm{tBq} / \mathrm{mmol}$ (Amersham, UK) at 9:00 $h$. The animals of both fed and unfed groups were killed one hour after injection. The distal segment of the esophagus and the entire small intestine were removed. The length of small intestine was measured and five short segments were taken at $0-1 \%, 25 \%$, $50 \%, 75 \%$ and $100 \%$ of the whole length of the organ, $0-1 \%$ corresponding to duodenum; this procedure is useful for comparative purposes between the different ages, avoiding differences due to growth. The samples were opened laterally on small cards, fixed in Carnoy for $6 \mathrm{~h}$ and embedded in hydroxyethyl methacrylate (LKB-Technovit $7100)$. Sections of $2 \mu \mathrm{m}$ were processed for the autoradiographic technique. Slides were covered with photographic emulsion (Ilford $\mathrm{K} 5)$, stored in light-proof boxes at $4^{\circ} \mathrm{C}$ for 4 weeks, developed with Kodak D19b, fixed and rinsed in distilled water. The samples were stained with hematoxylin-eosin. Labeling indices (LI) were obtained for the proliferating compartments. For the esophagus, 
this coincided with the basal layer of the epithelium and in the small intestine the whole crypt was used for the counting. Only crypts cut lengthwise were used for random counts. In order to assess changes in LI in regions of the crypt, spatial distribution curves were obtained, and the crypts were divided into arbitrary zones according to the lines of an integration eyepiece (Zeiss No. 1); these lines limited spaces or zones that were used to determine the LI for each zone. Fourteenday-old crypts contained 4 zones; due to growth, 18- and 22-day-old crypts had 5 zones. A single observer counted about 2,500 epithelial cells per segment per animal to obtain the LI. The crypt depth and villus height were determined in longitudinally sectioned material by the image analysis system (Mini-Mop, Kontron, Germany), using the same samples that were used to obtain the LI. A single observer measured 20 crypts and 10 villi from each site in each animal.

\section{Statistical analysis}

Differences between groups (food-deprived and control) were determined by the Student $t$-test. Within group differences were evaluated by one-way analysis of variance (ANOVA) and the differences associated with age or with intestinal segments were determined. Post-ANOVA tests were performed in these groups. The functional relationship between crypt depth or villus height and body weight was estimated by regression analysis (14). Regression curves were prepared for each small intestine segment and then presented as a single curve. The slopes obtained were compared for significant differences between treatments by the Student $t$-test (14). The level of significance was set at $\mathrm{P}<0.05$.

\section{Results}

No gross or microscopic injury occurred after food deprivation. The 14-, 18- and 22- day-old rats lost $16.8 \%, 11.8 \%$ and $9.6 \%$ of their body weight, respectively, after food deprivation.

\section{Morphology and labeling index of the esophageal epithelium}

At all ages studied the esophageal epithelium was already keratinized. Mitoses were found in the basal layer. The number of layers and thickness of the epithelium of fasted and control rats did not change at the ages studied (data not shown).

Food deprivation decreased the LI in the esophageal epithelium of 14- and 18-dayold rats, and had no effect on 22-day-old rats (Figure 1). In the fed group, the LI of 22-dayold rats was significantly lower than at younger ages, but in the fasted group this parameter was not different (Figure 1).

\section{Labeling index of the small intestine}

The spatial distribution curves for LI along the crypt demonstrated that the proliferating compartment extended throughout the crypt, both in control and in food-deprived animals, at each age studied. In 14-day-old fed rats, the percentage of labeled cells was small at the first position at the crypt bottom and increased toward the crypt-villus junction, and the LI was higher than in the unfed group in all crypt zones (Figure 2). In 18-day-old fed rats, crypt zones 3, 4 and 5 showed higher LI than the unfed group (Table 1). The LI of 22-day-old fed rats did not differ

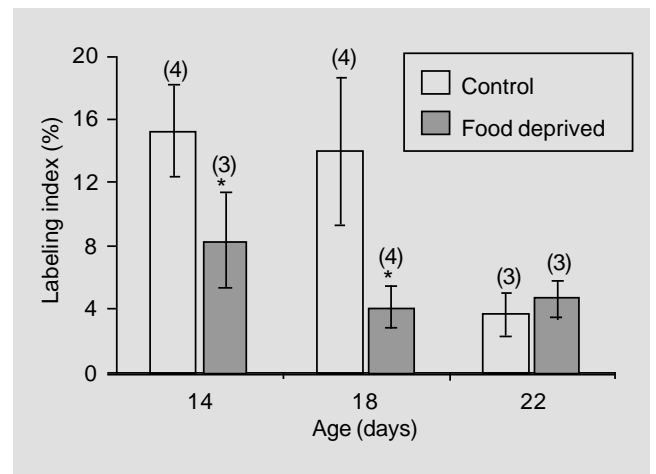

Figure 1 - Effect of food deprivation on $\mathrm{LI}$ in the esophagus of 14-, 18- and 22-day-old rats. Data are reported as the means \pm SD of four or three animals (within parentheses). ${ }^{*} \mathrm{P}<0.05 \mathrm{com}$ pared to control animals (Student $t$-test) 
Figure 2 - Labeling index distribution curves for the small intestine crypt of fed and food-deprived 14-day-old rats. Data are reported as the means \pm SD of five intestinal segments of four animals. ${ }^{*} \mathrm{P}<0.05$ compared to control animals (Student $t$-test).

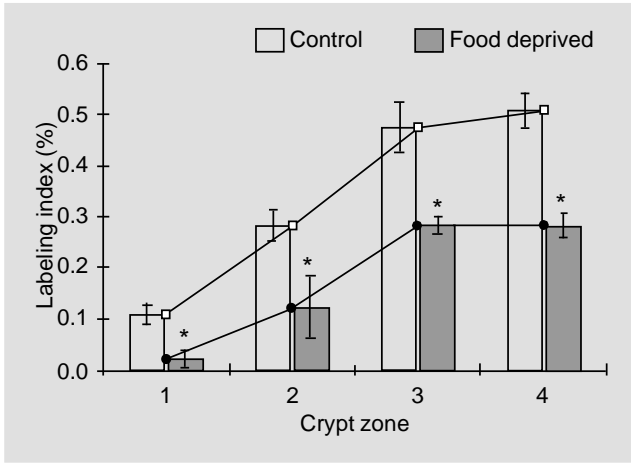

Table 1 - Labeling index (LI) of crypt zones in the small intestine of fed and fooddeprived 18- and 22-day-old rats ( 1 = crypt bottom; 5 = crypt top).

Values are reported as means (\%) of five intestinal segments \pm SD. ${ }^{*} \mathrm{P}<0.05$ compared to control (Student $t$-test).

\begin{tabular}{llclll}
\hline Crypt zones & \multicolumn{2}{c}{$\begin{array}{c}\text { LI (18-day-old }) \\
(\mathrm{N}=4)\end{array}$} & & \multicolumn{2}{c}{$\begin{array}{c}\text { LI (22-day-old }) \\
(\mathrm{N}=3)\end{array}$} \\
\cline { 2 - 3 } \cline { 6 - 6 } & Food deprived & Control & & Food deprived & Control \\
\hline 1 & $10.6 \pm 2.6$ & $13.4 \pm 6.8$ & & $20.8 \pm 9.1$ & $15.2 \pm 6.1$ \\
2 & $24.8 \pm 5.4$ & $28.0 \pm 6.6$ & & $29.3 \pm 3.7$ & $25.1 \pm 6.5$ \\
3 & $34.1 \pm 5.2^{*}$ & $42.3 \pm 2.2$ & & $35.5 \pm 3.7$ & $35.1 \pm 3.8$ \\
4 & $36.6 \pm 4.8^{*}$ & $45.3 \pm 1.2$ & & $34.3 \pm 2.3$ & $35.5 \pm 1.1$ \\
5 & $33.9 \pm 2.4^{*}$ & $41.0 \pm 1.4$ & & $26.5 \pm 2.3^{*}$ & $30.9 \pm 1.3$
\end{tabular}

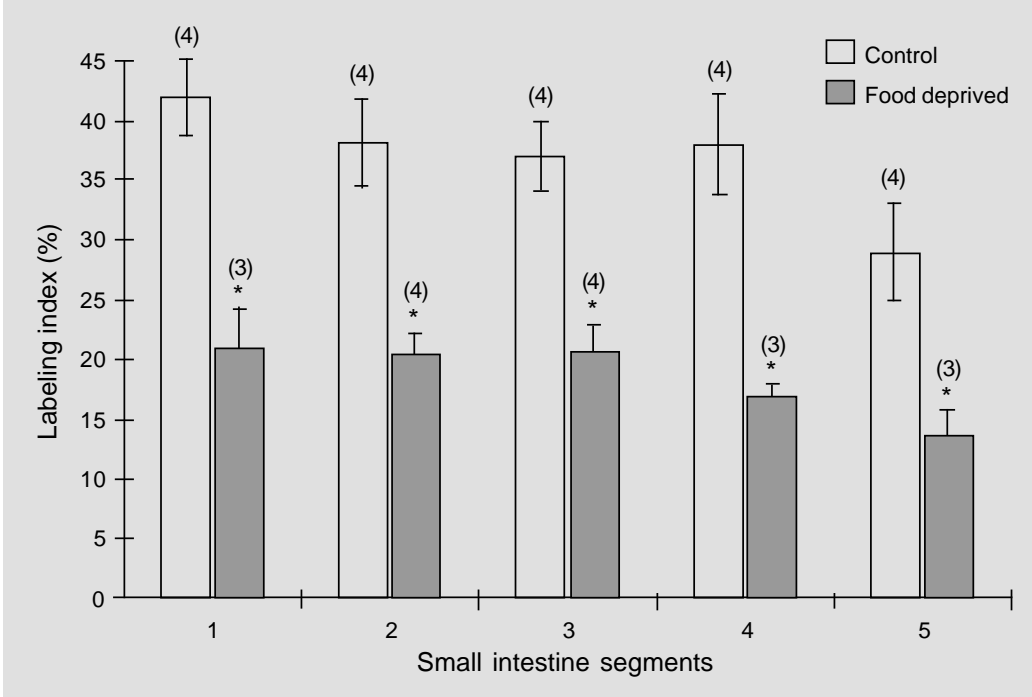

Figure 3 - Effect of food deprivation on labeling index of small intestine segments of 14-dayold rats. Data are reported as means \pm SD of four or three animals (within parentheses). ${ }^{*} \mathrm{P}<0.05$ compared to control animals (Student $t$-test). from the unfed group, except for the top crypt zone (Table 1).

Milk deprivation decreased the LI of all small intestine segments in 14-day-old rats (Figure 3). In 18-day-old unfed rats, only the LI of the distal segments were significantly lower than in the fed group (Table 2). The LI for 22-day-old fed and unfed rats did not differ significantly in any small intestine segment (Table 2).

When the LI of the segments were compared within age, only the last intestinal segment (ileum) of 14-day-old fed rats showed lower LI than all other animals in the same treatment (Figure 3).

\section{Measurement of crypt and villus size}

Crypt depth did not change after food deprivation (Table 3 ), but did increase throughout development, so that the shallowest crypt was seen in 14-day-old rats and the deepest in 22-day-old rats. The villus height of proximal intestinal segments of 14day-old unfed rats was decreased when compared to the fed group (Table 4). In 18-dayold unfed rats the villus height of most intestinal segments was shorter than in the fed group (Table 4). The villus height of intestinal segments of 22-day-old animals did not differ significantly between treatments (Table 4). The villus height was significantly smaller in the last segment (ileum) of 14- and 22day-old fed rats when compared to other segments and to 18-day-old villi. Indeed, there was a gradual shortening of distal villi in 18- to 22-day-old fed rats (Table 4).

\section{Relationship between crypt or villus size and body weight}

Regression curves were constructed to correlate the growth of the crypt or villus with the growth of the animal. The regression curves for crypt depth and body weight, which include all the small intestine segments, were positive, with significant linear- 
ity, in both treatments, but the highest slope and best correlation were obtained for the fed group (Figures 4 and 5). There was no significant difference between treatments. Villus height did not show dependence on body weight.

\section{Discussion}

In the present study the effect of milk or food deprivation on epithelial cell kinetics was investigated in the esophagus and small intestine of suckling and weanling rats. The results clearly demonstrate that milk deprivation inhibits cell proliferation in the esophagus and small intestine of suckling rats, but food deprivation does not alter proliferation
Table 2 - Effect of food deprivation on labeling index (LI) of small intestine segments of 18- and 22 -day-old rats $(0 \%=$ duodenum; $100 \%$ = distal ileum).

Values are reported as means $(\%) \pm \mathrm{SD}$. ${ }^{*} \mathrm{P}<0.05$ compared to control (Student $t$-test).

\begin{tabular}{llclll}
\hline $\begin{array}{l}\text { Segments } \\
(\%)\end{array}$ & \multicolumn{2}{c}{$\begin{array}{c}\text { LI (18-day-old }) \\
(\mathrm{N}=4)\end{array}$} & & \multicolumn{2}{c}{$\begin{array}{c}\text { LI (22-day-old }) \\
(\mathrm{N}=3)\end{array}$} \\
\cline { 2 - 3 } \cline { 5 - 6 } & Food deprived & Control & & Food deprived & Control \\
\hline 0 & $32.8 \pm 6.2$ & $36.7 \pm 1.0$ & & $31.7 \pm 3.0$ & $38.2 \pm 7.4$ \\
25 & $32.6 \pm 7.1$ & $33.6 \pm 3.1$ & & $31.7 \pm 3.2$ & $29.9 \pm 8.5$ \\
50 & $31.1 \pm 5.4$ & $38.6 \pm 6.8$ & & $30.6 \pm 5.1$ & $30.6 \pm 4.2$ \\
75 & $31.7 \pm 4.6^{*}$ & $40.9 \pm 1.0$ & & $31.8 \pm 3.6$ & $28.4 \pm 6.2$ \\
100 & $24.0 \pm 1.5^{*}$ & $36.2 \pm 3.0$ & & $27.1 \pm 4.6$ & $30.8 \pm 2.2$
\end{tabular}

Table 3 - Effect of food deprivation on crypt depth of 14-, 18- and 22-day-old rats.

Values $(\mu \mathrm{m})$ are reported as means \pm SD.

\begin{tabular}{|c|c|c|c|c|c|c|}
\hline \multirow[t]{2}{*}{$\begin{array}{l}\text { Segments } \\
(\%)\end{array}$} & \multicolumn{2}{|c|}{$\begin{array}{c}\text { 14-day-old } \\
(\mathrm{N}=4)\end{array}$} & \multicolumn{2}{|c|}{$\begin{array}{l}\text { 18-day-old } \\
\quad(N=4)\end{array}$} & \multicolumn{2}{|c|}{$\begin{array}{l}\text { 22-day-old } \\
\qquad(\mathrm{N}=3)\end{array}$} \\
\hline & Control & Food deprived & Control & Food deprived & Control & Food deprived \\
\hline 0 & $88.3 \pm 10.0$ & $82.5 \pm 6.9$ & $119.3 \pm 5.3$ & $118.4 \pm 16.3$ & $139.0 \pm 16.5$ & $123.5 \pm 20.6$ \\
\hline 25 & $74.8 \pm 3.0$ & $76.9 \pm 4.3$ & $91.4 \pm 7.3$ & $90.5 \pm 12.8$ & $114.2 \pm 28.3$ & $133.5 \pm 19.2$ \\
\hline 50 & $72.6 \pm 1.4$ & $81.7 \pm 2.9$ & $100.9 \pm 5.0$ & $92.2 \pm 17.1$ & $121.5 \pm 8.7$ & $120.5 \pm 6.5$ \\
\hline 75 & $79.6 \pm 7.2$ & $87.1 \pm 6.4$ & $107.7 \pm 15.9$ & $102.8 \pm 10.5$ & $120.1 \pm 23.2$ & $131.7 \pm 8.5$ \\
\hline 100 & $65.3 \pm 13.1$ & $74.6 \pm 5.2$ & $94.8 \pm 8.4$ & $79.9 \pm 8.9$ & $123.8 \pm 16.3$ & $111.4 \pm 8.7$ \\
\hline
\end{tabular}

Table 4 - Effect of food deprivation on villus height of 14-, 18- and 22-day-old rats.

Values $(\mu \mathrm{m})$ are reported as means $\pm \mathrm{SD} .{ }^{*} \mathrm{P}<0.05$ compared to control (Student $t$-test).

\begin{tabular}{|c|c|c|c|c|c|c|}
\hline \multirow[t]{2}{*}{$\begin{array}{l}\text { Segments } \\
(\%)\end{array}$} & \multicolumn{2}{|c|}{$\begin{array}{c}\text { 14-day-old } \\
(\mathrm{N}=4)\end{array}$} & \multicolumn{2}{|c|}{$\begin{array}{l}\text { 18-day-old } \\
(\mathrm{N}=4)\end{array}$} & \multicolumn{2}{|c|}{$\begin{array}{l}\text { 22-day-old } \\
\qquad(\mathrm{N}=3)\end{array}$} \\
\hline & Control & Food deprived & Control & Food deprived & Control & Food deprived \\
\hline 0 & $431.9 \pm 27.7$ & $292.7 \pm 47.5^{*}$ & $481.2 \pm 33.0$ & $386.5 \pm 41.1^{*}$ & $491.8 \pm 56.8$ & $435.5 \pm 35.1$ \\
\hline 25 & $443.4 \pm 17.1$ & $321.3 \pm 43.8^{*}$ & $497.3 \pm 81.2$ & $401.5 \pm 81.2$ & $453.7 \pm 35.1$ & $390.0 \pm 94.8$ \\
\hline 50 & $355.7 \pm 36.8$ & $312.9 \pm 43.4$ & $537.8 \pm 89.8$ & $365.5 \pm 74.9^{*}$ & $421.6 \pm 53.9$ & $345.1 \pm 50.8$ \\
\hline 75 & $292.3 \pm 56.9$ & $282.1 \pm 41.7$ & $481.9 \pm 54.1$ & $383.4 \pm 14.3^{*}$ & $353.1 \pm 73.5$ & $330.7 \pm 53.6$ \\
\hline 100 & $207.1 \pm 76.9$ & $203.4 \pm 42.6$ & $416.1 \pm 101.2$ & $250.1 \pm 49.1^{*}$ & $270.7 \pm 21.7$ & $259.1 \pm 36.1$ \\
\hline
\end{tabular}


Figure 4 - Relationship between crypt depth of control rats and body weight. Each point represents the mean of the small intestine segments of four animals.

Figure 5 - Relationship between crypt depth of food-deprived rats and body weight. Each point represents the mean of the small intestine segment for four animals.
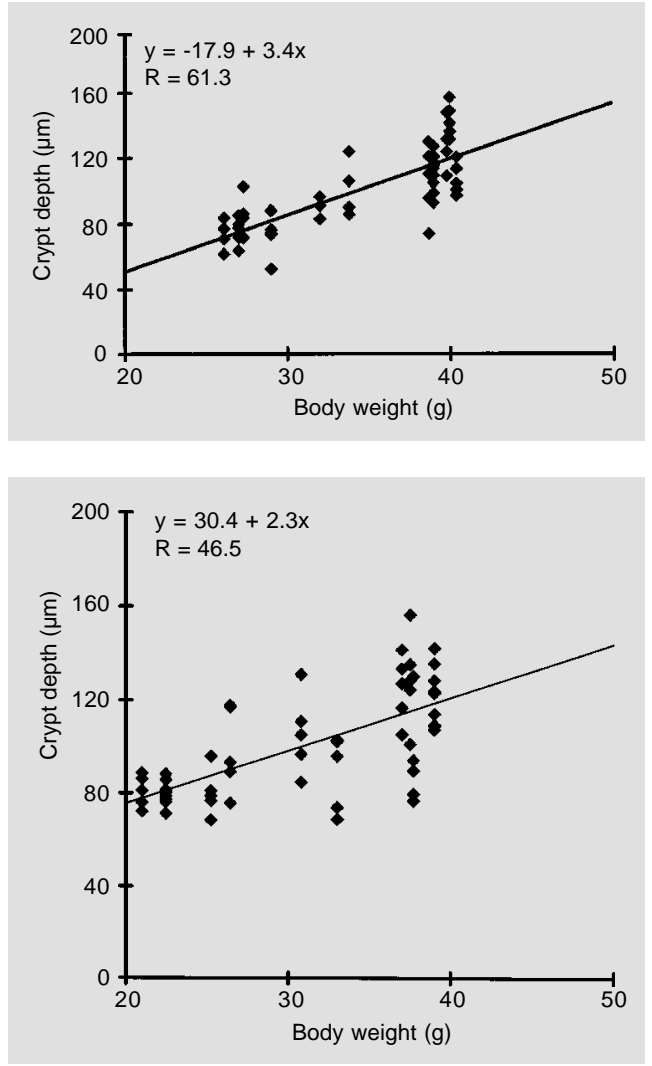

in newly weaned rats. The weanling period showed a transition of these effects.

The weight loss after food deprivation for $18-20 \mathrm{~h}$ was greater in the younger rats but still smaller than the corresponding loss found for adult rats after four days of starvation (10).

Cell proliferation in the esophageal epithelium has been poorly studied and no studies involving food deprivation have been reported even in adult animals. Adult mice submitted to a low-calorie diet showed a decrease in the labeling index of the esophageal epithelium (15). Raymond et al. (13) observed that the LI of the abdominal (distal) esophageal epithelium of mouse fetuses (18 days of gestation) is $17.9 \pm 2$. Similar results were obtained in the present study for 14- and 18-day-old fed rats $(15.3 \pm 3$ and $14.0 \pm 4.6$, respectively).

There was a slight decrease in LI in the intestine of control rats and villus height of distal regions, indicating a proximal-distal gradient, but the differences were only significant in the most distal region (ileum), as reported by other authors for adult animals $(16,17)$.

The crypts of young animals are short with less cells than adult crypts, so the cell count in crypt zones is similar to the individual cell count by cell position. Therefore, our distribution curves for the proliferating cell index in the crypts, although not constructed as a cell position LI, provided a rough estimate of LI plotted as a function of zone position in the crypt. Whereas in 14day-old rats milk deprivation decreased the LI in every crypt zone, at 18 and 22 days the significant differences were concentrated in the zones near the crypt-villus junction. This result may indicate the maturation of crypts from 14 to 18 days, but also suggests a delay in the migration of villus cells, as reflected by the accumulation of cells near the cryptvillus junction.

Crypt depth increased significantly along the ages studied, and villus height was unchanged, in agreement with the normal development of the rat (18-20). The heights of the villi were similar from 14 to 22 days of age $(18,19)$ or even decreased in the distal segments of the intestine (20). We also observed a slight decrease in the villus height of distal segments from day 18 to day 22 . Though the area of the villi, which provides the best stereological estimate of villus shape (21), was not measured in this study, the increase in villus length or width would have been significant only by day 24 (19).

The size of the proliferative compartment, estimated by crypt depth, remained constant both in fed and food-deprived animals in our study. However, due to the reduction in LI in the milk-deprived suckling rats, the transit time through proliferative and maturation compartments should also be decreased, as indicated by the reduction of villus height. The reduction of LI in suckling rats could be due to an increase in cell cycle time or to some cells escaping from the cell cycle to $\mathrm{G}_{0}$, as observed 
in adult animals (10). On the other hand, no delay in cell cycle was observed in the gastric epithelium of fasted suckling rats (4), in agreement with the stimulatory effect of fasting on the stomach (4).

When studying the expression of intestinal enzymes, Nsi-Emvo et al. (12) observed epithelial cell proliferation in food-deprived and control suckling rats aged 12 and 13 days. $\left[{ }^{3} \mathrm{H}\right]$-thymidine incorporation into DNA did not differ between control and $16 \mathrm{~h}$ fooddeprived rats, and crypt-villus height was similar in both groups. Yet, it should be noted that the use of mucosal scrapings and liquid scintillation spectrometry may not be the best method to estimate cell proliferation (22). However, in an autoradiographic study, cell migration showed a significant reduction in starved rats (12). Both decreased cell migration rate and DNA synthesis have only been described in the intestine of fasted neonatal rabbits, which also showed some regional differences (23).

No differences in LI or villus height were observed during the weanling period, indicating different control mechanisms during this stage of development. The small intestine of the rat undergoes a process of ontogenetic changes and maturation associated with weanling. During the first two weeks of postnatal life, when the rats are only suckling, high levels of lactase activity are detectable in their intestines (24). The fall in lactase activity coincides with the increase of sucrase-isomaltase activity during the third week of life, which corresponds to the weanling time (25). These maturation changes have been correlated with enhanced glucocorticoid levels (26) and increased epithelial cell migration rate (26). We have shown that plasma corticosteroid levels are highly elevated in food-deprived rats aged 18 and 22 days (27). However, administration of corticosterone inhibited epithelial proliferation of the stomach of fed suckling rats (27) but no effect could be demonstrated in the small intestine (28). Higher levels of corticoster- one were also obtained for suckling milkdeprived rats receiving prostaglandin $\mathrm{E}_{2}$ $\left(\mathrm{PDGE}_{2}\right)$ (29). These investigators demonstrated that $\mathrm{PDGE}_{2}$, which is present in milk, induced a significant increase in crypt depth. However, proliferative activity was not measured (29).

Many other factors and hormones are found in milk and there is a growing interest in the determination of their function in the epithelia of the gastrointestinal tract. Thus, it is worthwhile to check the effects of milkrestriction, as we did in the present study. We cannot explain why the stomach and the other organs of the gastrointestinal tract differed in their proliferative responses to food restriction in suckling rats, but we may suggest that the factors controlling the $\mathrm{G}_{1}-\mathrm{S}$ transition during the cell cycle in the stomach are not the same in the esophagus and small intestine, or may have been elicited only in the stomach. Another interesting and correlated difference between digestive organs may be the difference in protein synthesis found during development in the gastrointestinal tract of fasted rats. Burrin et al. (30) demonstrated that food deprivation decreases protein synthesis in the intestine but not in the stomach of suckling rats.

In conclusion, the present results describe the hypoproliferative responses to milk deprivation in the esophagus and small intestine of suckling rats, and the absence of response during the weanling period. We also conclude that the proliferative responses of the gastrointestinal tract cannot be generalized due to regional differences, since the stimulatory effect of milk deprivation on cell kinetics was specific for the gastric mucosa of suckling rats.

\section{Acknowledgments}

We thank Patrícia Gama for her invaluable help in preparing this manuscript. Thanks are also due to Mr. Cruz A.M. Rigonati for technical assistance. 


\section{References}

1. Koldovský O \& Thornburg W (1987). Hormones in milk: A review. Journal of Pediatric Gastroenterology and Nutrition, 119: 172-196.

2. Koldovský O (1989). Search for role of milk-borne biologically active peptides for the suckling. Journal of Nutrition, 119: 1543-1551.

3. Gama P \& Alvares EP (1996). LHRH and somatostatin effects on the cell proliferation of the gastric epithelium of suckling and weanling rats. Regulatory Peptides, 63: 73-78.

4. Alvares EP (1992). The effect of fasting on cell proliferation in the gastric mucosa of the 14-day old suckling rat. Brazilian Journal of Medical and Biological Research, 25: 641-649.

5. Alvares EP \& Gama P (1993). Fasting enhances cell proliferation of gastric epithelium during the suckling period in rats. Brazilian Journal of Medical and Biological Research, 26: 869-873.

6. Hunt TE (1957). Mitotic activity in the gastric mucosa of the rat after fasting and refeeding. Anatomical Record, 127: 539550.

7. Alvares EP (1987). Circadian rhythms of mitotic activity in gastric mucosa of feeding and fasting rats. Progress in Clinical and Biological Research, 227: 353-360.

8. Stevens-Hooper C \& Blair M (1958). The effect of starvation on epithelial renewal in the rat duodenum. Experimental Cell Research,14: 175-181.

9. Altmann GG (1972). Influence of starvation and refeeding on mucosal size and epithelial renewal in the rat small intestine. American Journal of Anatomy, 133: 391-400.

10. Al-Dewachi HS, Wright NA, Appleton DR \& Watson AJ (1975). The effect of starvation and refeeding on cell population kinetics in the rat small bowel mucosa. Journal of Anatomy, 119: 105-121.
11. Goodlad RA, Plumb JA \& Wright NA (1988). Epithelial cell proliferation and intestinal absorptive function during starvation and refeeding in the rat. Clinical Science, 74: 301-306.

12. Nsi-Emvo E, Foltzer-Jourdainne $C$, Raul F, Gosse F, Duluc I, Koch B \& Freund J (1994). Precocious and reversible expression of sucrase-isomaltase unrelated to intestinal cell turnover. American Journal of Physiology, 266: G568-G575.

13. Raymond C, Anne V \& Millane G (1991). Development of esophageal epithelium in the fetal and neonatal mouse. Anatomical Record, 230: 225-234.

14. Zar JH (1996). Biostatistical Analysis. 3rd edn. Englewood Clifts, Prentice Hall, NJ.

15. Lok E, Scott FW, Mongeau R, Nera EA, Malcolm S \& Clayson DB (1990). Calorie restriction and cellular proliferation in various tissues of the female Swiss Webster mouse. Cancer Letters, 51: 67-73.

16. Hagemann RF, Sigdestad CP \& Lesher $S$ (1970). A quantitative description of the intestinal epithelium of the mouse. American Journal of Anatomy, 129: 41-52.

17. Altmann GG \& Enesco M (1967). Cell number as a measure of distribution and renewal of epithelial cells in the small intestine of growing and adult rats. American Journal of Anatomy, 121: 319-336.

18. Koldovský O \& Herbst JJ (1973). Cell migration and cortisone-evoked decrease of acid B-galactosidase in the ileum of suckling rats. Gastroenterology, 64: 11421149.

19. Cummins AG, Steele TW, Labrooy JT \& Shearman DJC (1988). Maturation of the rat small intestine at weaning: changes in epithelial cell kinetics, bacterial flora and mucosal immune activity. Gut, 29: 16721679.

20. Trahair JF (1989). Remodeling of the rat small intestinal mucosa during the suckling period. Journal of Pediatric Gastroen- terology and Nutrition, 9: 232-237.

21. Ross GA \& Mayhew TM (1984). Effects of fasting on villi along the small intestine: a stereological approach to the problem of quantifying villus 'shape'. Experientia, 40: 856-858.

22. Wright N \& Alison M (1984). The Biology of Epithelial Cell Populations. Claredon Press, Oxford.

23. Baker SS \& Campbell C (1989). Shortterm malnutrition in neonatal rabbits: effect on gastrointestinal epithelial proliferation. Journal of Nutrition, 119: 785-789.

24. Yeh KY \& Moog F (1974). Intestinal lactase activity in the suckling rat: Influence of hypophysectomy and thyroidectomy. Science, 183: 77-79.

25. Henning SJ (1987). Functional development of the gastrointestinal tract. In: Johnson LR (Editor), Physiology of the Gastrointestinal Tract. 2nd edn. Raven Press, New York, 285-300.

26. Yeh KI, Yeh M \& Holt PR (1991). Thyroxine and cortisone cooperate to modulate postnatal intestinal enzyme differentiation in the rat. American Journal of Physiology, 260: G371-G378.

27. Gama P \& Alvares EP (1998). Corticosterone inhibits the cell proliferation of the gastric epithelium in suckling rats. Journal of Gastroenterology, 33 (in press).

28. Gama P \& Alvares EP (1996). Short-term corticosterone treatment: different effects in the gastrointestinal tract. Gut, 39 (Suppl 3): 149 (Abstract).

29. Marti A \& Fernandez-Otero MP (1994). Prostaglandin $E_{2}$ accelerates enzymatic and morphological maturation of the small intestine in suckling rats. Biology of the Neonate, 65: 119-125.

30. Burrin DG, Davis TA, Fioroto ML \& Reeds PJ (1991). Stage of development and fasting affect protein synthetic activity in the gastrointestinal tissues of suckling rats. Journal of Nutrition, 121: 1099-1108. 